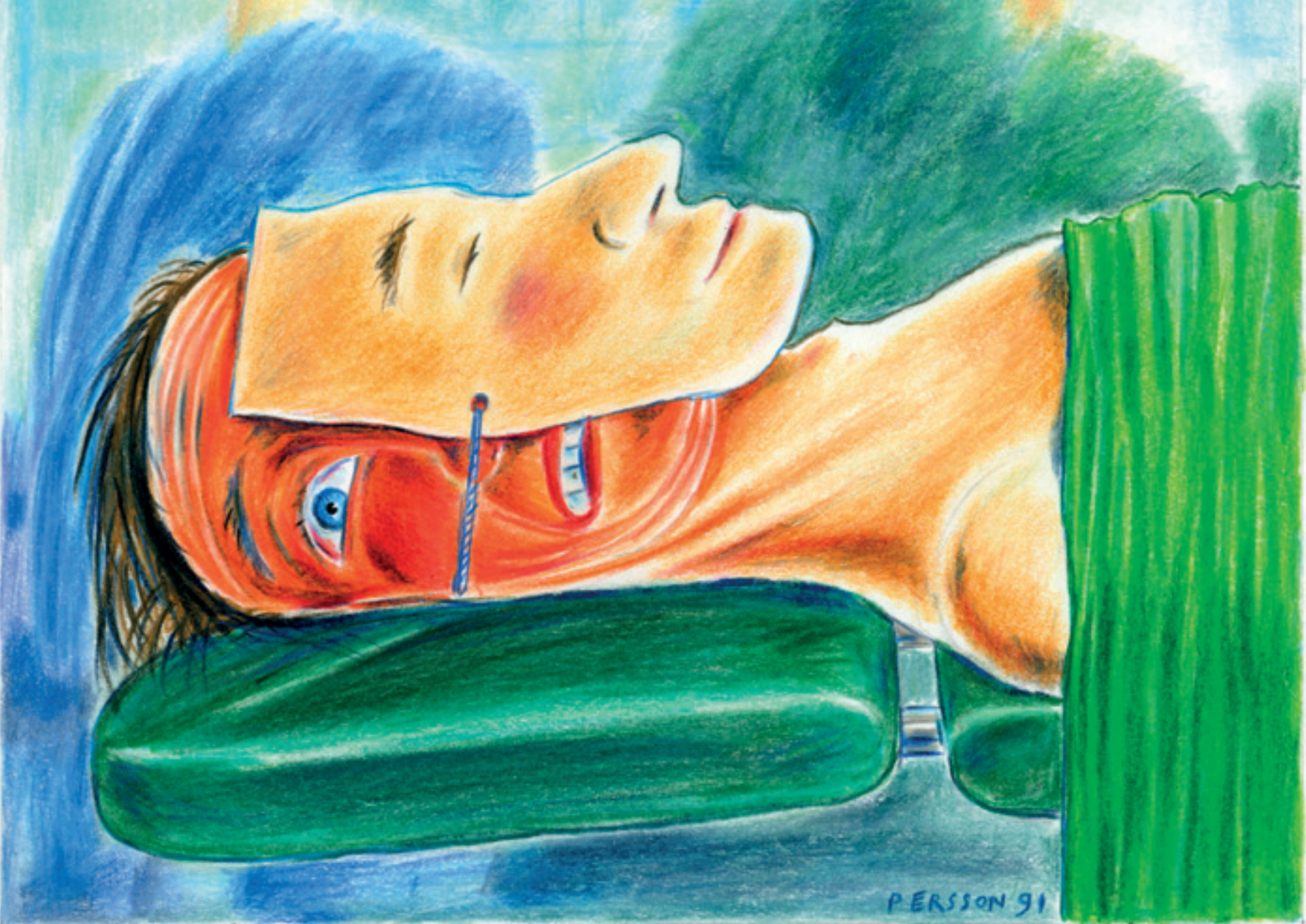

\title{
Vaken under narkos
}

Generell anestesi, eller «narkos» som det vanligen kallas, demonstrerades för första gången i Boston 1846, då Mr Gilbert Abbott befriades från en tumör på halsen (1). Under en lång följd av år var anestesi definitivt en konst, en balans mellan allt för djup anestesi som kunde leda till döden och allt för ytlig anestesi som omöjliggjorde kirurgi. Denna balansgång förenklades när curare introducerades 1942 och man kunde undvika störande reflexer under kirurgin utan att behöva tillföra anestesimedel $i$ koncentrationer som låg nära gränsen för cirkulationskollaps. Emellertid innebar farmakologisk muskelrelaxation även att en ny komplikation till narkos hade introducerats. Det blev nu fullt möjligt att en muskelparalyserad patient tillfördes så lite narkosmedel att medvetandet inte var släckt «awareness». Den första demonstrationen av narkos 1846 var faktiskt även det första fallet av awareness. Gilbert Abbott hade efter operationen klara minnesbilder av kirurgin, men hade inte känt någon smärta. Om situationen varit besvärlig för $\mathrm{Mr}$ Abbott hade han troligen förmedlat att han var otillräckligt sövd, men en patient som är muskelblockerad kan vara helt oförmögen att påvisa att han eller hon är vid medvetande. Det är alltså möjligt att en patient under operation kan vara vid medvetande utan att kunna röra sig och det är denna situation som Lasse B. Persson så väl illustrerar i sitt konstverk.

$\mathrm{Nu}$ är dock situationen oftast inte fullt så svår som den uttrycks i Perssons verk. Den vanligaste awareness upplevelsen är hörselintryck. Cirka $40 \%$ av patienter som kommer till medvetande under narkos är panikslagna (2), och det har ibland beskrivits som en känsla att man bevittnar sin egen död. Smärta i varierande grad upplevs av ungefär en lika stor andel. I likhet med andra starka negativa upplevelser kan awareness ge upphov till psykologiska symptom i efterförloppet. Det tycks som om något mindre än hälften av patienter med awareness drabbas av någon form av psykologiska sensymptom, oftast mardrömmar eller «flash-backs», som kan vara någon månad, men det finns även patienter som drabbas av livslångt posttraumatiskt stress syndrom (PTSD). Risken för en sådan svår efterföljd tycks vara högst $10 \%$ och sannolikt lägre (3).

Risken för awareness idag är cirka 0,2\% under narkos där muskelrelaxerande droger används (4). Några fullständigt säkra metoder för att detektera awareness finns fortfarande inte, men med hjälp av EEG-baserad neurofysiologisk monitorering tycks man kunna reducera denna risk till cirka $0,04 \%(5)$.

\section{Rolf Sandin}

rolfs@ltkalmar.se

Anestesi- och Intensivvårdsavdelningen Länssjukhuset S-39185 Kalmar

og

Institutionen för fysiologi och farmakologi Karolinska Institutet

Stockholm

\section{Peter Samuelsson}

Anestesi och Intensivvårdsavdelningen

Länssjukhuset

Kalmar

Oppgitte interessekonflikter: Ingen

\section{Litteratur}

1. Calverly RK. Anesthesia as specialty: past, present and future. I: Barash PG, Cullen BF, Stoelting RK reds. Clinical anesthesia. Philadelphia: JB Lippincott, 1989: 3-33.

2. Sandin R. Outcome after awareness with explicit recall. Acta Anaesthesiol Belg 2006; 57: 429-32.

3. Samuelsson P, Brudin L, Sandin RH. Late psychological symptoms after awareness among consecutively included surgical patients. Anesthesiology 2007; 106: 26-32

4. Sandin RH, Enlund G, Samuelsson P et al. Awareness during anaesthesia: a prospective case study. Lancet 2000; 355: 707-11.

5. Lennmarken C, Sandin R. Neuromonitoring for awareness during surgery. Lancet 2004; 363 1747-8.

Manuskriptet ble mottatt 19.2. 2010 og godkjent 25.2. 2010. Medisinsk redaktør Anne Gitte Hertzberg. 